\title{
NESEZDANÉ SOUŽITÍ - SOUČÁST PROMĚNY RODINY (přehledová studie)
}

Miluše Vítečková1, Iva Brabcová2

1Jihočeská univerzita v Českých Budějovicích, Pedagogická fakulta, katedra pedagogiky a psychologie 2Jihočeská univerzita v Českých Budějovicích, Zdravotně sociální fakulta, katedra ošetřovatelství

\section{Nesezdané soužití}

„Nesezdané soužitíi“ je asi nejfrekventovanější výraz pro dlouhodobější životní společenství dvou osob odlišného pohlaví, které žijí ve svazku podobném manželství, aniž by byly oficiálně sezdány (Rabušic, 2001; Hrušáková, Králičcková, 2006). Dalšími termíny, jež používají zahraniční odborníci pro toto životní společenství, jsou „společné soužití“ (living together), „konsenzuální svazek“ (consensual union), ,dvoustupňové manželstvi““ (two-step marriage), „,kamarádské manželstvi“" (companionate marriage), „manželství na zkoušku" (trial marriage) atd. Termín, který je většinou prijímán, je právě „nesezdané soužitíc neboli „nesezdaná kohabitace“ (unmarried cohabitation) (Rabušic, 2001, s. 193). Mưžeme se však také setkat $\mathrm{s}$ termínem „faktické manželstvi“" (Český statistický úřad, 2004), ale i se „životem na psí knížku“. Pro přehlednost je použit $\mathrm{v}$ textu pouze termín nesezdané soužití.

Ač je nesezdané soužití v současné době často skloňováno $\mathrm{v}$ nejrůznějších informačních zdrojích, nejde o nový jev, je znám již z dávných dob. $V$ současné době však dochází $\mathrm{k}$ nárůstu způsobu tohoto soužití, mění se jeho kvantita i kvalita a veřejností je oproti dobám minulým prrijímáno (především jako předstupeň manželstvî). V naší společnosti se společně s poklesem sňatečnosti, odkládáním sňatku do vyššího věku, nárůstem rozvodovosti a zvyšováním porodnosti mimo manželství začíná rozšiřovat od počátku devadesátých let. $\mathrm{V}$ západních zemích je výrazným znakem proměny populačního chování již od konce let šedesátých. Hamplová a Pikálková (2002) zmiňují v souvislosti s nesezdaným soužitím „moderní“ variantu partnerského života, což je pro tento jev asi nejpříznačnější adjektivum. Podle Rabušice (2001) se nesezdané soužití, dříve dokonce označováno za deviantní chování, stává $\mathrm{v}$ některých zemích sociální normou. I u nás, jak zmiňuje Šmolka (2002), se tento alternativní způsob života stává běžnou záležitostí nejen mezi nevěřícími. Stále častěji ho praktikují po čase i mladí věřící, přestože je v církvi toto soužití považováno za nemorální.

Singly (1999), ale i Rabušic (2001) a Možný (2002) zmiňují, že jde o soužití individualizované, orientované na seberealizaci každého z partnerů, soužití umožňující pocit individuální svobody a výrazné osobní identity. Možný (1999, s. 17-18) se však k individualismu v Česku nestaví príliš optimisticky: „Individualismus v Česku zvlčil: ztratil se z něho smysl pro odpovédnost, bez kterého se nutnè stává svou vlastní smutnou karikaturou. Kamsi se vytratila hrdost individua, že všechny jeho činy jsou morálně ospravedlnitelné, a bez této hrdosti nezůstává z individualismu nic než chytrácký utilitarismus a sobectví beze všech skrupulí." Za změnami rodinného chování je $z$ výše uvedeného vidět především změny hodnotové. Podle Hamplové (2003b) jde při posuzování demografických změn v těchto př́padech o normativní prístup. Naproti tomu je ještě druhý možný pohled na rozšíření nesezdaného soužití, který poukazuje na změnu objektivních podmínek (situace na pracovním trhu apod. - „to, co lidé mohou“). Jedná se o teorie racionální volby (Hamplová, 2003b). Na základě vlastního kvalitativního výzkumu (v letech 2008 až 2010 uskutečněna $\mathrm{v}$ rámci doktorského studia Miluše Vítečkové analýza nesezdaných soužití, ve kterých jsou vychovávány děti - 30 polostrukturovaných rozhovorů) je možné uvažovat o prolínání obou teorii, nebot' jsou spatřovány jak změny hodnotové, tak změny objektivních podmínek.

Podle Rabušice (2001) má rozšíření nesezdaného soužití souvislost také se změnou tradičního vzorce cesty do manželství (láska $\rightarrow$ chození spolu - námluvy $\rightarrow$ sňatek $\rightarrow$ pravidelný sex $\rightarrow$ děti). Fáze námluv bývá nahrazena právě nesezdaným soužitím. Sex již není podmíněn manželstvím, oslabuje se následnost vstup do manželství $\rightarrow$ rodičovství. Zvyšuje se počet 
nesezdaných soužití, do kterých se rodí děti. Nejedná se tedy pouze o nesezdané soužití „,na zkoušku“ před vstupem do manželství, ale v posledních desetiletích se ve vzrůstající míre stává i alternativou $\mathrm{k}$ manželství. $\mathrm{V}$ době, kdy se snižuje plodnost párů, může být nesezdané soužití i „čekáním na úspěšné otěhotněni", které $\mathrm{v}$ př́padě úspěchu většinou končí sňatkem až po narození dítěte.
Fázování životního cyklu (podle Rabušice, 2001) z hlediska uzavírání a rozpadu partnerských svazků nesezdaného soužití (př́klady nejčastějších kombinací vzájemného fázování sňatků, rozvodů a nesezdaných soužití - kohabitacî) znázorňuje obrázek 1.

1.

Sňatek

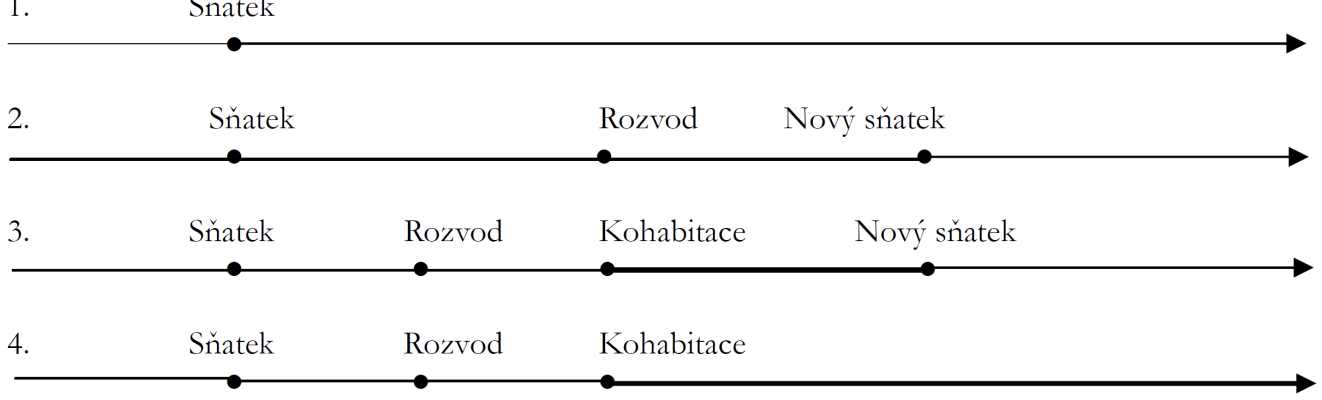

5. Kohabitace Sňatek
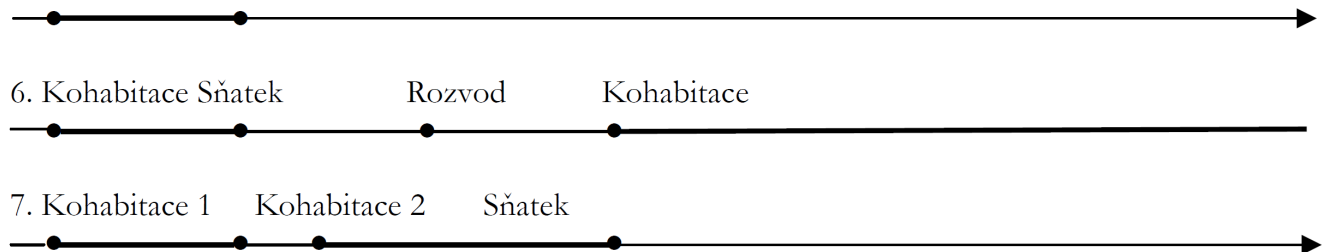

8. Kohabitace Sňatek

Rozvod

Kohabitace Sňatek

9. Kohabitace

10. Kohabitace $1 \quad$ Kohabitace 2

Zdroj: Rabušic (2001, s. 196)

Obr. 1 Různorodost fázování partnerských svazků během životního cyklu v současných vyspělých společnostech

Nesezdané soužití může mít různé podoby. Mưže jít o krátkodobé soužití, ale i o dlouhodobý vztah, do kterého se rodí děti a je alternativou manželství. Na základě určitých faktorů jsou vytvořeny kategorie (typologie) nesezda- 
dobné dělení (do tř́i vyhraněných a jedné přechodné formy kohabitantů). Mládek a Širočková (2004) zmiňují dva základní typy, které dále člení na dva subtypy: 1) předmanželské kohabitace [a) kohabitace jako testování partnerství („manželství“ na zkoušku), b) kohabitace jako předstupeň manželství]; 2) kohabitace jako dlouhodobé účelové spolužití [a) kohabitace jako alternativa manželství, b) kohabitace jako funkční partnerství]. Bumpass a Sweet (1989) rozlišují typy nesezdaných dle délky trvání vztahu: 1) vztahy, které trvají prúibližně 2 roky a potom končí bud' vstupem do manželství, nebo rozchodem; 2) vztahy trvající do pěti let (předstupeň manželstvî); 3) dlouhotrvající vztahy, u nichž je malá pravděpodobnost, že končí manželstvím (asi 1/10 nesezdaných párů). Sandra Buchler et al. (2009) při výzkumu sociálních a demografických vlastností nesezdaně žijících v Austrálii užívá typologie, která dělí nesezdané páry podle vůle uzavřít manželství a podle předchozího manželského stavu (tzn. zda byli, či nebyli sezdáni). Všechny typologie lze zestručnit tak, jak to udělala Hamplová (2002), která dělí nesezdané páry pouze na ty: 1) které mají v úmyslu vstoupit do manželství; 2) bez úmyslu uzavřít sňatek. Problémem zařazování do těchto typologií je fakt, že není možné určit, jak tyto vztahy dopadnou. Při kategorizování lze vycházet pouze ze situace, která předcházela současnému stavu, tedy $\mathrm{z}$ toho, zda se jedná o svobodné, rozvedené či ovdovělé a dále je pak možné pouze hovořit o určitém úmyslu do budoucna. Zde je však možné vidět úskalí, nebot' úmysl je něco, co není uchopitelné, pevně dané, konstantní.

Nejvýstižnější se zdá být typologie Buchler et al. (2009), avšak vzhledem k tomu, že jde současně o soužití dvou lidí, může dojít i k situaci, kdy mají partneři odlišnou představu o vztahu a o jeho budoucnosti. V tomto pŕípadě lze tedy hovořit o určitém kompromisu, který v typologiích postrádáme. Šmolka (2004) vidí navíc $\mathrm{v}$ této souvislosti $\mathrm{v}$ této situaci úskalí nesezdaného soužití, kdy by dal jeden z partnerů přednost tradičnímu manželství a druhý méně tradiční formě soužití.

\section{Rozšíření nesezdaného soužití}

Statistické zmapování nesezdaného soužití je problematické, špatně zachytitelné. Údaje o nesezdaném soužití, o jeho výskytu lze nalézt v sociologických a demografických průzkumech, tudíž je zde určitá míra nepřesnosti. Podstatné rysy však vysledovat jde a určitá data existují. $Z$ nich je možné vyčíst, že je nesezdané soužití nejvíce rozšířeno ve Švédsku a v Dánsku, dále pak na Islandu. Skandinávské země byly prvními průkopníky, mezi kterými se po druhé světové válce začaly rozšiřovat jiné formy soužití než manželství. V současné době se tu rodí mimo manželství každé druhé dítě. Nejméně je nesezdané soužití rozšířeno především v zemích jižní Evropy (Španělsko, Portugalsko, Itálie, Řecko) a Irsku (Rabušic, 2001; Chaloupková, Šalamounová, 2004; Kiernan, 2004).

V Čechách proběhly první průzkumy týkající se nesezdaného soužití v letech 1985-86, následně byly zopakovány v období 1990-91. Nebyly provedeny na celé populaci, ale týkaly se pouze snoubenců, kteří $\mathrm{v}$ té době uzavírali sňatek ( $v$ těchto prípadech se tedy jednalo ve $100 \%$ o nesezdané soužití jako předstupeň manželstvî). O výsledcích informovali Možný a Rabušic (1992). Z výzkumu je patrné, že již $\mathrm{v}$ těchto letech docházelo $\mathrm{k}$ nepatrnému zvýšení nesezdaných párů (ze 46 \% v období 1985-86 na $48 \%$ v období 1990-91) (Rabušic, 2001). Na základě těchto údajů je možné konstatovat, že již začátkem devadesátých let předcházelo každému druhému manželství nesezdané soužití. Vzhledem k tomu, že je v současné době z velké části fáze „chozeni““ nahrazována nesezdaným soužitím, je pravděpodobné, že by toto procento bylo daleko vyšší. Zmíněné údaje se vztahovaly pouze ke snoubencům. Pokud se zaměříme na širší spektrum dotazovaných, celkovou populaci starší 18 let, byla dalšími šetřeními International Social Survey Program (dále jen ISSP) 1994 „Rodina a gender role“ a ISSP 2002. Jde o dlouhodobý mezinárodní výzkumný projekt. Cílovou populací je populace České republiky starší 18 let. V roce 1994 (ISSP 1994) jde o údaje o 1024 respondentech, v roce 2002 (ISSP 2002) bylo dotázáno 1289 respondentů. Podle získaných údajů žilo v nesezdaném soužití v roce 1994 5,7\% respondentů, v roce 2002 se jejich podíl zvýšil na $8 \%$ (Chaloupková, 2006a). Narůst nesezdaného soužití dokládá i výzkum TSS 1999 (šetření sociální stratifikace a mobility). Velikost výzkumného souboru, který byl vybrán náhodnou volbou, činila 4744 osob ve věku 18-69 let. Šlo o součást projektu „Deset let transformace české a slovenské spo- 
lečnosti“ řešeného na Sociologickém ústavu AV ČR. Z údajů tohoto šetření vyplývá, že v té době bylo v nesezdaném soužití $6,3 \%$ populace (Tuček, 2000). Nárůst nesezdaného soužití je vidět i ze srovnání údajů ze Sčítání lidu, domů a bytů $z$ let 1991 a 2001 . V tabulce 1 je uvedeno zastoupení nesezdaných soužití v úhrnu úplných rodin v letech 1991 a 2001. Výhodou těchto údajů je možné rozlišení nesezdaných soužití bezdětných a s dětmi. Nevýhodou je, že není patrné, zda se jedná o děti z předchozích vztahů či narozené do nesezdaných soužití. Současně je možné přepokládat, že je výskyt nesezdaného soužití v datech Sčítání lidu, domů a bytů pod- hodnocen, nebot' jde pouze o ty, jež se v bytovém listu označili jako druh či družka ve vztahu $\mathrm{k}$ uživateli bytu, kteří mají shodné trvalé bydliště. Ti, co mají rozdílné trvalé bydliště, přestože žijí nesezdaně, i ti, jež žijí nap̌r. v bytě, domě u rodičů, zachyceni nejsou. Mohou chybět i páry, kdy se muž a žena jako druh a družka neoznačili.

Ze všech zmíněných výzkumů je tedy patrné, že dochází k rozšíření počtu těch, kteří žijí $\mathrm{v}$ nesezdaném soužití, že dochází $\mathrm{k}$ nárůstu nesezdaného soužití, tudíž lze konstatovat v této oblasti progresivní vývoj.

Tabulka 1 Nesezdaná soužití a jejich zastoupení v úhrnu úplných rodin v letech 1991 a 2001

\begin{tabular}{lccccc}
\hline & \multicolumn{2}{c}{1991} & \multicolumn{2}{c}{2001} & Př́růstek, \\
& Abs. & $\%$ & abs. & $\%$ & úbytek \\
\hline Úplné rodiny celkem & 2512893 & 100,0 & 2333592 & 100,0 & -179301 \\
Z toho nesezdaná soužití & 84934 & 3,4 & 125269 & 5,4 & 40335 \\
Úplné rodiny bez dětí & 1117025 & 100,0 & 1242822 & 100,0 & 125797 \\
Z toho nesezdaná soužití & 45449 & 4,1 & 73850 & 5,9 & 28401 \\
Úplné rodiny s dětmi & 1395868 & 100,0 & 1090770 & 100,0 & -305098 \\
Z toho nesezdaná soužití & 39485 & 2,8 & 51419 & 4,7 & 11934 \\
\hline & & & Zdroj: Český statistický úřad (2004)
\end{tabular}

V letech 2005-06 provedl Český statistický úřad ještě šetření Životní podmínky 2006 (EU SILC 2006). Do tohoto šetření bylo zahrnuto 4286 opětovně navštívených domácností z šetření z roku 2005 a nově 5750 náhodně vybraných domácností z celého území České republiky. Z tohoto šetření vyplývá, že je v České republice celkem přes 4 miliony domácností (v 64,2\% domácností žije úplná rodina - úplné rodiny čisté nebo s dalšími příbuznými, 11,2\% jsou neúplné rodiny, 23,7\% jsou domácnosti jednotlivců a zbývající $1 \%$ tvoří nerodinné domácnosti). Jako faktická manželství (tedy nesezdané soužití) se označilo $11 \%$ párů. Na celkovém počtu domácností se faktická manželství podílela 6,2\% (Český statistický úřad, 2008).

Stejně tak jako u nás koncem dvacátého století klesá míra uzavírání manželských svazků a narůstá počet nesezdaných soužití, dochází $\mathrm{k}$ proměně populačního chování, $\mathrm{k}$ těmto jevům, jak uvádějí Hoem et al. (2009), také v Rusku, Rumunsku, Bulharsku a Mad'arsku. Ve většině zemí východní Evropy je možné zevšeobecnit fakt, který uvádějí Bradatan a Kulcsar (2008) v souvislosti s Mad'arskem. Poukazuji na patrný vliv sledování zahraničních trendů, na to, že lidé žijící v Mad'arsku jsou stále mnohem více vystaveni vzorům chování západních zemí. Je tedy i zde možné předpokládat, že se počet nesezdaně žijících zvýší i v budoucnu. Dle Seltzera (2000) lze na základě výzkumu z let devadesátých i u amerických rodin očekávat, že i ony budou pokračovat v tomto trendu. Uvádí, že se tyto vztahy mohou brzy stát pevnou institucí, současně je však velmi nepravděpodobné, že budou mít přednostní postavení před manželstvím a rozením, výchovou dětí v manželství. 
Tento trend je patrný např. i ve Velké Británii (Kiernan, 2004), Austrálii (Dempsey, De Vaus 2004).

Porovnat výskyt nesezdaného soužití s ostatními evropskými státy je pak možné na základě šetření ISSP 2002 (viz výše). Ve Švédsku žilo v této věkové skupině (starší 18 let) v sezdaném svazku osm lidí ze sta, avšak skoro každý druhý mladý respondent žil v nesezdaném soužití. $\mathrm{V}$ podílu nesezdaných svazků pak následovaly Francie a Nizozemí. Méně než pět dotázaných ze sta žilo v neformálním svazku na Slovensku a v Polsku (Chaloupková, Šalamounová, 2004). Na Slovensku navíc dokonce dochází $\mathrm{k}$ opačnému jevu než v ostatních státech. V roce 1980 bylo podle Štatistického úradu Slovenskej republiky (2009) 31,2 tis. nesezdaných soužití a v roce 1991 se tento počet snížil na 20,9 tis. Podle Pilinské et al. (2005) došlo $\mathrm{k}$ tomuto poklesu zřejmě $\mathrm{v}$ důsledku strachu ze zneužití deklarovaných údajů. Při dalším sčítání v roce 2001 došlo k nárůstu na 30,5 tis. nesezdaných soužití. Ač z údajů Štatistického úradu Slovenskej republiky za rok 2008 vyplývá, že počet uzavřených manželství byl v roce 2008 nejvyšší od roku 1993, pokračuje současně odklad uzavření manželství do vyššího věku. Sňatečnost je na Slovensku však velmi nevyzpytatelná, tudíž není možné vyloučit pokles, kolísavý vývoj. Nelze odhadnout, jak se postaví mladá generace právě $\mathrm{k}$ nesezdanému soužití, zda ho bude považovat za předstupeň manželství či se ve větší míře prosadí jako celoživotní forma partnerského soužití (Štatistický úrad Slovenskej republiky, 2009). I když se manželství na Slovensku dle Pilinské et al. (2005) těší velké popularitě, lze očekávat, že počet osob žijících $\mathrm{v}$ manželství bude $\mathrm{s}$ největší pravděpodobností klesat. Je pravděpodobné i to, že bude počet nesezdaného soužití stoupat, nebot' je pro mladé projevem moderního životního stylu (Pilinská et al., 2005).

Přestože dochází $\mathrm{k}$ nárůstu nesezdaného soužití (z výzkumů výše uvedených je vidět nárůst $\mathrm{v}$ časových posunech), ke zvyšujícímu se počtu dětí narozených mimo manželství (data Českého statistického úradu ukazují, že se v České republice během posledních desetiletí výraznè zvýšil podíl dětí narozených mimo manželství - v roce 2009 dosahoval 38,8\%, v roce 1989 to bylo pouze $7,9 \%$ ) a na základě šetření SEPM 2006 (Sociální a ekonomické podmínky mateřství. Bylo prvním specializovaným reprezentativním šetrenim, které bylo zaměrené na sociální, ekonomickou a rodinnou situaci neprovdaných matek $v$ kontextu vdaných matek $v$ České republice po roce 1989. Tento výzkum byl zaměren na ženy, jejichž dèti se narodily od poloviny devadesátých let do počátku roku 2006. Celkem bylo dotazováno 1160 žen.) jde přibližně v polovině případů o děti narozené do nesezdaných soužití, lze konstatovat dle Hamplové (2000); Hamplové et al. (2003) a Černé (2005), že v české společnosti představuje nesezdané soužití spíše předstupeň než alternativu manželství.

Kdo jsou ti, kteří žijí v nesezdaném soužití? Již podle Možného a Rabušice (1992), kteří informovali o prvních průzkumech nesezdaného soužití u snoubenců (1985-86, následně zopakovaných v období 1990-91 - viz výše), bylo nesezdané soužití nejrozšířenější u lidí $\mathrm{s}$ nižším vzděláním. Vzhledem $\mathrm{k}$ tomu, že je nesezdané soužití charakteristické především pro ty, kteří jsou ekonomicky samostatní, kteří již „bytovou otázku“ vyřešili (Vymětalová, 2000), je logickým závěrem, že jde tedy především o ty, kteří mají nižší vzdělání, nebot' se na pracovní trh dostávají dříve než studenti, kteří jsou samostatní až později. $V$ tomto př́padě jde tedy o skupinu mladých svobodných lidí. I zjištění ze zahraničí poukazují na rozšírení nesezdaného soužití mezi těmi, jež mají nízké vzdělání (Thornton et al., 1992; Bradatan, Kulscar, 2008; Lichter, Qian, 2008). Tato zjištění je možné podložit i výsledky Sčítání lidu, domů a bytů, kde nesezdanými byli převážně lidé se základním vzděláním a vyučení. Přesto dochází $\mathrm{v}$ průběhu devadesátých let $\mathrm{k}$ určité změně nárůstu lidí s vyšším vzděláním, zejména středoškoláků s maturitou (Český statistický úřad, 2004). I z šetření SEPM 2006 (viz výše) vyplývá, že matkami, které mají dítě mimo manželství $\mathrm{v}$ nesezdaném soužití, jsou ženy s vyšším (zejména středoškolským) vzděláním (Hamplová, 2007). Hamplová (2003b) však na základě šetření ISSP 2002 (viz výše) uvádí, že získaná data nepotvrzují, že by v České republice vzdělání ovlivňovalo, zda lidé vstoupí do prrímého manželství nebo zda začnou žít se svým partnerem bez sňatku. Nižší intenzita sňatečnosti vzdělanějších mužů i žen je dle ní daná tím, že tito lidé déle studují, tudíž sňatky pouze odkládají.

Podle Českého statistického úřadu (2004) bylo mezi základními charakteristikami nesezda- 
ných soužití v České republice v roce 2001: zhruba polovina osob byla ve věku do 40 let; většinou se jednalo o osoby rozvedené a svobodné; věrících osob byla v nesezdaném soužití zhruba čtvrtina. Z údajů Českého statistického úřadu (2004) také vyplývá, že změny věkové struktury osob žijících $\mathrm{v}$ nesezdaných soužitích byly nejvýraznější změnou v období 1991-2001. Nejdynamičtější vývoj mezi roky 1991 a 2001 zaznamenala faktická manželství dvou svobodných - většinou mladých - partnerů. Podíl těchto rodin se $\mathrm{v}$ tomto období téměř ztrojnásobil a dosáhl v roce 2001 zhruba čtvrtiny z celkového počtu nesezdaných soužití. Podíl nesezdaných soužití s partnery vyššího věku poklesl. V rámci výzkumu TSS 1999 (viz výše) bylo zjištěno, že z $6,3 \%$ žijících v nesezdaném soužití bylo $3,3 \%$ svobodných, 2,7 \% rozvedených a $0,3 \%$ ovdovělých (Tuček, 2000). Podle Českého statistického úřadu (2008) a jeho šetření EU-SILC 2006 (viz výše) bylo nesezdané soužití mezi sociálními skupinami nejčastější u nezaměstnaných, z hlediska věku mezi mladšími, $z$ hlediska pŕíjmu na osobu mezi nejchudšími a nejbohatšími a podle počtu dětí mezi bezdětnými a mnohodětnými.

\section{Postoje k nesezdanému soužití}

Je nesezdané soužití vnímáno jako nová forma rodiny? Jaká je tolerance vůči nesezdanému soužití a jaké je reálné chování? V průzkumu Rodina 96 (realizován Sociologickým ústavem AV $\check{C} R$, účastnilo se ho 1496 respondentů, byl zaméřen na postoje lidí všech věkových kategorií) uvedlo $65 \%$ respondentů, že ,je v pořádku, když spolu lidé žijí, aniž by plánovali sňatek“ (Kučera, 2000). Na základě výsledků výzkumu provedeného v roce 1997 (sociologické šetření „Mladá generace“ - realizováno Sociologickým ústavem $A V \check{C} R$. Zaměřneno na rodinné a reprodukční chování mladých svobodných lidí, postoje $k$ manželství a rodičovství, objasnění vnějších podmínek, plány týkající se demografického chování. Výzkumný vzorek - 1320 mladých svobodných lidí ve věku 18-30 let) považuje téměř $70 \%$ mladých svobodných lidí nesezdané soužití jako vhodný předstupeň manželství („manžel-ství na zkoušku“) a přibližně desetina z nich předpokládá, že by žila ve volném svazku trvale. Většina mladých lidí však svými postoji dokládá, že za „normálni““ je stále považován trvalý život v manželství (Hamplová, 2000). Z šetření ISSP 1999 (ISSP 1999 - náboženství, uskutečněno na zadání Sociologického ústavu AV $\check{C} R$ agenturou $S C \& C-1224$ dotázaných) je vidět nárůst podpory nesezdaného soužití na zkoušku, kdy je nejčastěji plánovanou formou budoucího partnerského života mladých dosud svobodných lidí. Že je rozumné, aby lidé, kteř́ se chtějí vzít, spolu nejprve žili, odpovědělo $72 \%$ dotazovaných (Hamplová, Pikálková, 2002). V roce 2000 byl uskutečněn demografický výzkum Population Policy Attitudes and Acceptance Surveys (PPA II). Šlo o druhou vlnu, o pokračování evropského komparativního výzkumu The Acceptance of Population Related Policies (PPA I - 1991). Uskutečnil se v devíti evropských zemích včetně České republiky, kde proběhl na přelomu řína a listopadu roku 2001 a účastnilo se ho 1094 respondentů. Naše společnost se projevila jako jednoznačně promanželsky orientovaná. Celoživotní nesezdané soužití a LAT (Living Apart Together - „oddělené společné soužiti““, kdy jde o trvalý vztah, ale každý žije zvlášt') by volilo jen $7 \%$ z dotázaných, což mimo jiné potvrzuje, že nesezdané soužití představuje $\mathrm{v}$ naší společnosti spíš předstupeň sňatku než alternativu manželství (Hamplová, 2003a). V šetření ISSP 2002 (viz výše) se objevily výroky: „Je dobré, když lidé, kteří hodlají uzavřít sňatek, spolu nejdříve žijí.“ „Je v pořádku, když lidé spolu žijí, aniž by plánovali sňatek. " První výrok podporovalo $73 \%$ respondentů, druhý výrok se těšil o něco menši podpoře (55\%) (Chaloupková, Šalamounová, 2004). V rámci výzkumu Naše společnost 2009 (projekt kontinuálního výzkumu veřejného mínění - Centrum výzkumu veřejného mínění Sociologického ústavu $A V \check{C} R$, dotazováno 1082 obyvatel České republiky ve věku od 15 let) byl zjišt'ován souhlas (prípadně nesouhlas) s vybranými výroky o partnerském soužití a rodičovství v čase. Z něho je patrné, že se výrazně snížila podpora výroku o důležitosti manželství pro výchovu dětí (z $52 \%$ v roce 2003 na $36 \%$ v roce 2009). Výrazně též klesl počet lidí, kteří se domnívají, že sňatek má být uzavřen před narozením dítěte (o $17 \%$ oproti roku 2003) (Šamanová, 2010). Lze tedy konstatovat, že se zvětšuje tolerance $\mathrm{k}$ různým formám partnerského soužití, které tvoři alternativu k tradičnímu manželství.

\section{Postoje versus reálné chování}

Šetření rodiny a reprodukce (FFS) z roku 1997 zachycuje nejen deklarované postoje, ale i reálné 
chování, čímž je možné doplnit výše zmiňované postoje. Výzkum vycházel z mezinárodního projektu Fertility and Family Survey, cílem bylo zkoumání reprodukčního chování v evropském regionu. V České republice bylo dotázáno 1700 žen, 700 mužů ve věku 15-44. Výsledky FFS pak překvapivě ukazují, že ačkoli mladí lidé na rovině postojů preferují př́edmanželské nesezdané soužití, reálné chování je poněkud tradičnější (Hamplová, Pikálková, 2002). Z analýzy (podsoubor osob ve věku 25 až 35 let - 3677 respondentů) Haškové a Rabušice (2008), kteří vycházeli z šetření „Manželství, práce a rodina" (2005) (realizováno agenturou SC \& $C$ v roce 2005, reprezentativní vzorek 2546 mužů a žen ve věku 20-40 let) a šetření „Souvislosti proměn pracovního trhu a forem soukromého, rodinného a partnerského života $\mathrm{V}$ české společnosti“" (Proměny, 2005) (realizováno Centrem pro výzkum veřejného mínění Sociologického ústavu $A V$ $\check{C} R$ v roce 2005 na souboru 5510 mužü a žen ve věku 25-54 let) vyplývá, že rychlý pokles sňatečnosti po roce 1998 z důvodu poklesu hodnoty manželství pro mladé lidi silnou oporu $\mathrm{v}$ datech nenachází. Spíše jde o odklad manželství. Ačkoli manželskou rodinu chápe většina mladých svobodných lidí jako model pozitivní, pro celou polovinu z nich není tím modelem uspořádání soukromého života, který by pro sebe v ideálním př́padě aktuálně zvolili. Téměř polovina $z$ nich by preferovala manželskou rodinu, necelá třetina by pak volila nesezdané soužití (s dětmi nebo bez nich) a téměř pětina některou $z$ individualizovaných forem uspořádání soukromého života bez dětí, zejména partnerství se dvěma domácnostmi (LAT); zanedbatelný podíl by se rozhodl pro život bez stálého partnera/partnerky. I z šetření SEPM 2006 (viz výše) vyplývá (Chaloupková, 2006b, 2007), že většina neprovdaných matek považuje za ideální partnerské uspořádání život v manželství po předchozím společném nesezdaném soužití „na zkoušku“. Pouze pětina neprovdaných žen považuje za ideální formu dlouhodobé nesezdané soužití. Př́ímému manželství (bez nesezdaného soužití) by dávalo přednost téměř $8 \%$ neprovdaných matek.

$\mathrm{Na}$ základě zmapování výsledků výzkumů $z$ let 1997-2009 je patrný posun k větší toleranci nesezdaného soužití, snižování podpory výroků týkajících se důležitosti manželství pro výchovu dětí. V postojích i v reálném chování dochází k oslabení manželství jako instituce, přesto je patrné, že reálné chování je oproti postojům tradičnější. Stále je nesezdané soužití vnímáno především jako předstupeň manželství.

\section{Motivace pro život v nesezdaném soužití}

Jak zmiňuje Giddens (1999), v př́padě nesezdaného soužití většinou nejde o plánované rozhodnutí, ale o stav, který postupně vyplyne ze vztahu samotného. Většina těchto párů má $\mathrm{v}$ úmyslu se někdy $\mathrm{v}$ budoucnu nechat oddat. Jak tyto vztahy dopadnou, však není možné dopředu říci. To, že dochází $\mathrm{k}$ rozšíření nesezdaného soužití, dávají různí autoři do různých souvislostí. Podle Rabušice (2001) vidí jedni důvod v menší závislosti žen na mužích, druzí $\mathrm{v}$ pečlivějším hledání vhodného partnera. Zmiňuje, že jde o prrirozený vývoj, který je reakcí na současné kulturní a ekonomické podmínky, a nesezdané soužití je logickým řešením životní fáze mezi zahájením sexuálního života a sňatkem, nebot' toto „meziobdobí“ trvá až deset let. Uvádí, že již v druhé polovině šedesátých let považovaly první švédské páry nesezdané soužití za alternativu „přežilé“ manželské instituce (Rabušic, 2001). Hamplová a Pikálková (2002) dávají do souvislosti vliv tolerance společnosti $\mathrm{k}$ nesezdanému soužití a $\mathrm{v}$ důsledku toho nepotřebnost mladých lidí svůj vztah formálně stvrzovat. Singly (1999) spojuje nesezdané soužití s projevem „postmoderní“ rodiny, kdy vztahy již samy o sobě nemají hodnotu. Přitažlivá není „št'astná rodina“, ale št'astný jednotlivec. Dalším velmi rozšířeným názorem (Bologne, 1997; Kuchařová, 2003; Keller, 2005) je to, že se lidé přizpůsobují okolnostem, jako jsou časté střídání zaměstnání, „flexibilizace“ práce, změna bydliště. Lidé jsou pak zaměřeni především na současnost a dochází $\mathrm{k}$ váhání s plány do budoucna. Jäckelová (1997) a Kiernan (2004) dávají rozšíření nesezdaného soužití do souvislosti s nárůstem počtu rozvodů, kdy pro sebe páry hledají nové, alternativní formy soužití. Mưže jít právě o reakci na tuto nejistotu. Dủvodem pro volbu nesezdaného soužití může být (Edin, 2000; Walter, 2001) i ekonomické zajištění ze strany muže, kdy ženy podmiňují manželství stabilním zaměstnáním muže a jeho dostatečným přímem. Hamplová (2000) uvádí jako důvod $\mathrm{k}$ výběru nesezdaného soužití možnost snadného rozchodu. Ti, co preferovali celoživotní nesezdané soužití, na něm navíc oceňovali, že jim poskytuje nezávislost. V př́padě nese- 
zdaného soužití „,na zkoušku“ doufali, že v něm mnohem lépe poznají partnera jako vlastního budoucího manžela a vyzkouší pevnost vzájemného vztahu. Kiernan (2004) též uvádí jako důvody žen pro nesezdané soužití vyhýbání se pojmu závislost, která je obvykle implicitní při uzavření manželství. Ženy mohou být nervózní, že manželství může změnit rovnováhu sil v partnerství. Někdy bývá uváděn i samotný fakt, že jde o možnost trávit více času společně.

Výzkumným šetřením SEPM 2006 (viz výše) bylo v oblasti motivace, důvodů pro to, že ženy nevstoupily před porodem dítěte do manželství (u žen, které žily s otcem dítěte), zjištěno, že častěji souhlasily s výroky, které představují odmítání instituce manželství; častěji souhlasily s tím, že manželství je formalita; častěji uváděly, že sňatek neuzavřely, protože to pro ně bylo výhodné a protože svatba by byla moc nákladná; častěji rovněž odpovídaly, že se nechtěly vdávat těhotné. Pro osamělé matky byl častější důvod ten, že sňatek odmítal partner nebo že jejich partner byl ženatý. Jediným důvodem, kde se postoje nesezdaně žijících a osamělých matek shodoval, byla obava ze ztráty nezávislosti (Chaloupková, 2007). Omezení tohoto šetření je v tom, že jde pouze o výpovědi žen a chybí informace mužů.

\section{Nesezdané soužití versus manželství}

Lze položit mezi nesezdané soužití a manželství rovnítko? Přestože nesezdaní uvádějí, že je manželství především formalitou, že se tato dvě soužití liší pouze formálním statutem, na základě zjištění demografů, sociologů, psychologů tomu tak není. Hned prvním rozdílem, který uvádí jak Bologne (1997), tak Plaňava (1998) či např. Vágnerová (2000), je v nesezdaném soužití absence důležitého rituálu, kterým je svatba. Tímto dnem vzniká nové společenství a současně dochází $\mathrm{k}$ uvědomění si přechodu od dospívání $\mathrm{k}$ dospělosti. I podle Cherlina (2004) jsou nesezdaná soužití neúplnou institucí, přičemž role takto žijících jsou méně vymezené a nejsou svázány jasnými sociálními normami.

$\mathrm{V}$ tomto textu se zaměŕíme na rozdíl mezi nesezdaným soužitím a manželstvím ve stabilitě, organizaci domácnosti, péči o dítě, hospodaření a kontaktech s širší rodinou.

Pokud jde o stabilitu obou forem soužití, někteří autoři neshledávají výrazný rozdíl. Podle Rabušice (2001) dochází ve stejné míre k rozvo- dům jako $\mathrm{k}$ rozpadům nesezdaných soužití. Rozdíl je vukončení vztahu, nebot' rozvod manželství je právně ošetřen, zákon určuje majetkové vyrovnání podle jasných právních nařízení, kdežto po rozpadu nesezdaného soužití nejsou žádná pravidla vytvořena. Podle Šetření rodiny a reprodukce 1997 (viz výše), které zmiňuje Hamplová (2001), bylo naopak zjištěno, že nejméně stabilními svazky byla nesezdaná soužití (někdy se hovoří o tzv. efektu nesezdaného soužití - cohabitation effect). To, že jsou manželské rodiny stabilnější než nesezdané svazky, bylo potvrzeno i na základě šetření SEPM 2006 (viz výše) (Hamplová, 2007). Brown a Booth (1996) v souvislosti se stabilitou zmiňují, že je nutné také rozlišit ty, jež uvažují v budoucnu o svatbě, a ty, jež plánují dlouhodobé nesezdané soužití. Nesezdaní, kteří si hodlají svého partnera vzít, mohou brát své současné životní uspořádání jako odrazový můstek k manželství, a tak se role nejasnosti snižuje a kvalita vztahu zvyšuje. Dokonce uvádí, že $76 \%$ nesezdaných vztahů není jiných než manželství, pokud se týká kvality vztahu. Do kvality vztahu se však také odráží př́tomnost biologických dětí, dětí z minulých svazků i předchozí zkušenosti se vztahy. Přítomnost dětí bývá př́ćcinou sporů. Výzkumné šetření, které proběhlo v USA v roce 1995 a které rozšírili Wu a Musick (2008), se zaměřilo na stabilitu rodin $z$ pohledu páru, na odhad rizika rozchodu po prvním porodu. Zkoumaným souborem byly páry, které se vzaly před narozením prvního dítěte, a páry, které se po narození dítěte hodlají v budoucnu vzít. Nejvyšší nestabilita byla pozorovaná u párů, které žijí v nesezdaném soužití při narození prvního dítěte a pak se ožení, ve vztahu k těm, kteří se vezmou přímo a poté mají dítě (Wu, Musick, 2008). I Osborne et al. (2007) uvádějí, že nesezdaní rodiče vykazují dvaapůlkrát vyšší pravděpodobnost rozchodu, než je tomu v prípadě manželství. Lichter a Qian (2008) uvádějí, že má na stabilitu vztahu vliv i opakované nesezdané soužití. To se však odráží především jako problém ke stabilitě následného manželství. Pro manželství je po sériových nesezdaných soužitích žen pravděpodobnost rozvodu více než dvojnásobná než u těch, které žily nesezdaně pouze s jejich budoucím manželem. Současně je obtížná po opakovaných nesezdaných soužitích transformace nesezdaného soužití do manželství. Kiernan (2004) uvádí, že rozdíl v křehkosti, 
stabilitě vztahu může být způsobený i tím, že lidé vstupující do manželství si rozvážněji vybírají svého partnera - víc uvažují, s kým chtějí dlouhodobě žít.

Šetření „Muži a ženy v ČR: životní dráhy a mezigenerační vztahy (2005)“ (Longitudinální výzkum, jenž je součástí mezinárodního programu Generations and Gender Programme. Dotazováno 10006 mužů a žen ve věku 18-79 let z celé České republiky) umožnilo vhled do organizace domácnosti jak v manželství, tak v nesezdaném soužití. Žádné významné odlišnosti nebyly zjišš těny. V obou typech soužití se na chodu domácnosti podílí ze dvou třetin žena. Mírné rozdíly podle typu partnerství je možné zaznamenat v oblasti zajištění péče o děti. Do činností spojených s péčí o děti se nesezdaní muži zapojují v menší míře než ženatí. Tendenci k rovnoměrnější péči o děti mají svazky stvrzené sňatkem (Höhne, 2008).

Srovnáním dat z šetření ISSP 1994 a ISSP 2002 (viz výše) je možné vysledovat hospodaření s př́ijmy. Partneři žijící nesezdaně si častěji než manželské páry ponechávají alespoň část svých prríjmů mimo „společnou kasu“. Ukazuje se však, že podíl nesezdaných párů, které mají zcela oddělené účty, výrazně poklesl. Toto může naznačovat, že se mění vzorce hospodaření nesezdaných párů, že se přibližuje hospodaření manželských dvojic. Je současně možné předpokládat, že společné hospodaření bude u párů, které mají děti (bez ohledu na to, zda jsou sezdáni, či nikoliv). Naopak lze očekávat, že ke společnému hospodaření budou zdrženlivější páry, které spolu žijí kratší dobu (Chaloupková, 2006a). Ze shrnutí analýzy J. Chaloupkové (2006a) vyplývá, že největší šanci hospodařit odděleně mají bezdětné páry a páry, ve kterých má alespoň jeden z partnerů zkušenost s rozpadem vztahu. Společné hospodaření je spojeno s větší vzájemnou důvěrou mezi partnery, vyššími pocity závazku a větším očekáváním trvalosti svazku, oddělené pak s větším pocitem nespokojenosti s rodinným životem. Největší pravděpodobnost společného hospodaření mají manželské páry se dvěma a více dětmi.

V Nizozemí proběhl výzkum zjišst'ující rozdíl mezi nesezdanými a manželskými páry, pokud jde o četnost kontaktů s vlastní rodinou a rodinou partnera. Bylo zjištěno, že k interakci mezi nesezdaně žijícími a vlastními rodiči, ale i rodiči partnera dochází méně často než u sezdaných. S ostatními členy rodiny nebyl zjištěn výrazný rozdíl mezi typem soužití. Tato zjišsění naznačují, že nesezdaní mohou být méně citliví na normativní závazky, než je tomu u sezdaných, že jsou méně pevně zakotveni v rodinné síti. Je možný i vliv menšího uznávání tradičních hodnot, městské prostředí, nižší religiozita, větší nejistota v budoucnost partnerství, ale i podpora členů rodiny apod. Je však možné konstatovat, že obecně méně kontaktů s př́buznými mají ti, kteří jsou méně orientováni na rodinu (Hogerbrugge, Dykstra, 2009).

Hamplová a Pikálková (2002) shrnují rozdíly mezi manželstvím a nesezdaným soužitím mj. do těchto bodů:

- $\quad$ pro manželství je typický společný étos, lidé v nesezdaných soužitích jsou orientováni spíše individualisticky;

- $\quad$ pro manželství jsou charakteristické společné investice, $v$ nesezdaném soužití se klade vyšší důraz na momentální „př́nos“ partnera;

- v nesezdaném soužití jsou méně príijímané tradiční rodinné hodnoty a mužské a ženské role, je menší pravděpodobnost, že vytvoří pevný a dlouhý vztah.

Nesezdané soužití tedy nelze považovat za rovnocenné manželství, přesto jde o určitou alternativu $\mathrm{k}$ manželství, která s ním má určité shodné rysy.

\section{ZÁVĚR}

Nesezdaná soužití často vznikají především $z$ důvodu možnosti společného bydlení. $V$ dřívějších dobách vztah po období „námluv“ končil sňatkem, či rozchodem, v současné době již není prítomen pocit potřeby vztah formálně stvrzovat a do nesezdaných soužití se rodí i děti. Pokud jde o plány do budoucna, většina žijících $\mathrm{v}$ nesezdaném soužití má $\mathrm{v}$ úmyslu někdy v budoucnu uzavřít se svým partnerem sňatek (pouze $\mathrm{v}$ př́padech nesezdaných, kteří již manželstvím prošli, bývá plánování manželství zastoupeno méně). Vzhledem $\mathrm{k}$ tomu, že není možné určit, jak vztah dopadne, lze konstatovat, že otázka svatby je v budoucnu téměr u všech otevřená.

V souvislosti s nesezdaným soužitím je třeba zmínit nárůst počtu dětí narozených mimo manželství, přičemž jde přibližně v polovině 
případů o děti narozené do nesezdaných soužití. I proto je nesezdanému soužití v současné době věnována větší pozornost. Je možné ho považovat za rizikový jev nejen $\mathrm{v}$ rámci rodiny, ale i v rámci širšího sociálního kontextu. Cílem tohoto textu bylo seznámení s vybranými aspekty nesezdaného soužití v českém i zahraničním kontextu.

Přestože je Česká republika v postojích k nesezdanému soužití velmi liberální, stále jsme ještě především státem orientovaným pro manželství. Liberální přístup má však vliv na rozšíření nesezdaného soužití. Toto je možné doložit i tím, že $\mathrm{v}$ dřivějších dobách bylo zaznamenáno více těhotných nevěst a $\mathrm{v}$ současné době, kdy dítě mimo manželství není překážkou, stigmatem, je manželství uzavíráno (nebo neuzavíráno) až po narození dítěte.

Nesezdané soužití je spojováno především s těmi, jež mají nižší vzdělání. Oproti matkámsamoživitelkám, u nichž je velké zastoupení žen se základním vzděláním, je $\mathrm{v}$ př́padě nesezdaného soužití vyšší pravděpodobnost, že jde o páry se středním vzděláním. Současně jde především o ty, jež mají zkušenost $\mathrm{s}$ manželstvím. V posledních letech však dochází mezi nesezdanými páry $\mathrm{k}$ nárůstu počtu mladých svobodných.

$\mathrm{Na}$ otázku, proč se stává nesezdané soužití stále rozšířenějším jevem, lze tedy rríci, že jde o jev, který reflektuje vývoj společnosti. Jev, který je dáván např. do souvislosti se zvyšováním počtu rozvodů a $\mathrm{v}$ důsledku toho s obavami z manželství, změnami hodnot. Zmiňováno je kladení dưrazu na osobní štěstí. Z šetření, která jsou zaměřena na důvody, motivaci nesezdaných pro život $\mathrm{v}$ nesezdaných soužitích, vyplývá, že manželství je považováno především za formalitu a nepřináší žádné výhody. Dalšími uváděnými důvody jsou těhotenství, nákladná svatba, nejistota vztahem, ale i nezávislost.

Ačkoliv nesezdaní dávají manželství do souvislosti s pouhou formalitou, není možné mezi nesezdané soužití a manželství klást rovnítko, nesporně existují rozdíly. $\mathrm{Na}$ základě českých i zahraničních výzkumů lze konstatovat, že nesezdané soužití lze považovat za křehčí a méně stabilní vztah. I když se to může jevit jako nepodstatné, i absence svatebního rituálu je nejen rozdílem, ale může být i určitým problémem. Současně ani termín pro ty, kteří žijí bez uzavření manželství, není jednotný. Z nesezdaného soužití také vyplývají menší právní jistoty. Každodenní fungování manželských i nemanželských rodin, stejně tak jako jejich hospodaření, však nevykazuje podstatné rozdíly.

Je nutné si uvědomit, že nesezdané soužití má spoustu podob, forem a vzhledem $\mathrm{k}$ tomu, že není možné určit, jak tyto vztahy dopadnou, je obtížné zařazování do určitých kategorií. Stále je však pravděpodobnější, že jde spíše o „předstupeň manželství “ než o nahrazení manželství. Lze však také očekávat, že $\mathrm{v}$ budoucnu může dojít $\mathrm{k}$ nárůstu počtu těch, kteří budou žít $\mathrm{v}$ nesezdaném soužití dlouhodoběji, že se nesezdaná soužití stanou běžnějšími.

* Výzkum je uskutečňován s částečnou finanční podporou ze strany GA ZSF JU č. 901-1041109.

\section{LITERATURA}

BOLOGNE, J. C.: Svatby: Dějiny svatebních obřadi̊ na západě. 1. vyd. Praha: VOLVOX GLOBATOR, 1997. $390 \mathrm{~s}$.

BRADATAN, C., KULCSAR, L.: Choosing between Marriage and Cohabitation: Women's First Union Patterns in Hungary. Journal of Comparative Family Studies, 2008, vol. 39, no 4, s. 491-507.

BROWN, L. S., BOOTH, A.: Cohabitation versus Marriage: A Comparison of Relationship Quality. Journal of Marriage and Family, 1996, vol. 58, no 3, s. 668-678.

BUCHLER, S. et al.: The social and demographic characteristics of cohabiters in Australia. Familly Matters [online]. 2009, no 82, s. 22-29. [cit. 2009-10-01].

BUMPASS, L. L., SWEET, J. A.: National estimates of cohabitation. Demography, 1989, vol. 26, no 4, s. 615625.

ČERNÁ, K.: Pohled na kohabitaci a rodinu v České republice a Velké Británii z hlediska Evropské studie hodnot. Demografie, 2005, vol. 47, no 2, s. 87-95.

Český statistický úřad. Faktická manželství $v$ datech Sčítání lidu, domů a bytů 2001 [online]. Zveřejněno dne 23. 12. 2004, aktualizováno 26. 10. 2006 [cit. 2008-1001]. Dostupné z: < http://www.czso.cz/csu/edicniplan.nsf/ $\mathrm{p} / 4125-04>$

Český statistický úrad. Nesezdaná soužití - faktická manželství [online]. Zveřejněno dne 8. 4. 2008, aktualizováno 21. 4. 2008 [cit. 2008-10-01]. Dostupné z:

http://www.czso.cz/csu/2007edicniplan.nsf/ t/210037FDBF/\$File/113707a2.5.pdf.

DEMPSEY, K., DE VAUS, D.: Who cohabits in 2001? The significance of age, gender, religion and ethnicity. Journal of Sociology, 2004, vol. 40, no 2, s. 157-178.

EDIN, K.: What Do Low-Income Single Mothers Say about Marriage? Social Problems, 2000, vol. 47, no 1, s. $112-133$. 
GIDDENS, A.: Sociologie. 1. vyd. - dotisk. Praha: Argo, 1999. s. 155-182.

HAMPLOVÁ, D.: Postoje k manželství a rodičovství. In: Fialová, L. et al.: Představy mladých lidí o manželství a rodičovství. 1. vyd. Praha: Sociologické nakladatelství, 2000, s. 67-98.

HAMPLOVÁ, D.: Výsledky šetření rodiny a reprodukce (FFS). In: Rychtař́iková, J. et al.: Diferenciace reprodukčního a rodinného chování vevropských populacích. (Sociologické texty SP 01:10). 1. vyd. Praha: Sociologický ústav AV ČR, 2001, s. 43-72.

HAMPLOVÁ, D.: Marriage and Cohabitation: Qualitative Differences in Partnership arrangements. Sociologicky časopis/Czech Sociological Review, 2002, vol. 38, no 6, s. $771-788$

HAMPLOVÁ, D.: Preferované partnerské uspořádání: sociodemografické a hodnotové rozdíly. Demografie, 2003a, roč. 45, č. 3, s. 166-176.

HAMPLOVÁ, D.: Vstup do manželství a nesezdaného soužití v České republice po roce 1989 v souvislosti se vzdéláním. (Sociologické texty SP 03:4), 1. vyd. Praha: Sociologický ústav AV ČR, 2003b, 52 s.

HAMPLOVÁ, D.: Děti bez partnera nebo na psí knížku? In: Hamplová (ed.) et al.: Děti na psí knížku? Mimomanželská plodnost $v \breve{C} R$. 1. vyd. Praha: Sociologický ústav AV ČR, 2007, 155 s.

HAMPLOVÁ, D., PIKÁLKOVÁ, S.: Manželství, nesezdané soužití a partnerský vztah. In: Mansfeldová, Z., Tuček, M. (ed.): Současná česká společnost. Sociologické studie. Praha: Sociologický ústav AV ČR, 2002, s. 127-147.

HAMPLOVÁ, D., RYCHTAŘÍKOVÁ, J., PIKÁLKOVÁ, S.: České ženy. 1. vyd. Praha: Sociologický ústav AV ČR, 2003, $108 \mathrm{~s}$.

HAŠKOVÁ, H., RABUŠIC, L.: K nízké sňatečnosti v České republice. Sociální studia (Partnerství, rodičovství, rodina), 2008, vol. 5, no 2, s. 9-33.

HOEM, J. M. et al.: Traces of the Second Demographic Transition in Four Selected Countries in Central and Eastern Europe: Union Formation as a Demographic Manifestation. European Journal of Population, 2009, vol. 25, no 3, s. 239-255.

HOGERBRUgGe, J. A. M., DYKSTRA, A. P.: The Family Ties of Unmarried Cohabiting and Married Persons in the Netherlands. Journal of Marriage and Family, 2009, vol. 71, no 1, s. 135-145.

HÖHNE, S.: Význam partnerství pro harmonizaci rodiny a zaměstnání. In: Sirovátka, T., Hora, O. (eds.): Rodina, déti a zaměstnání v české společnosti. 1. vyd. Boskovice: Albert, 2008, s. 119-143.

HRUŠÁKOVÁ, M., KRÁLÍČKOVÁ, Z.: České rodinné právo. 3. vyd. Brno: Masarykova univerzita a Doplněk, 2006. $400 \mathrm{~s}$.

CHALOUPKOVÁ, J.: Dohromady, nebo každý zvlášt'? Hospodaření s př́ijmy manželských a nesezdaných párů. Sociologický časopis/Czech Sociological Review, 2006a, vol. 42, no 5, s. 971-986.

CHALOUPKOVÁ, J.: Neprovdané matky: Základní data z výzkumného šetření sociální a ekonomické podmínky mateřství. In: Hamplová, D. et al.: Nemanželská plodnost: její rizika a sociální podmínky. 1. vyd. Praha: Sociologický ústav AV ČR, 2006b, s. 10-13.

CHALOUPKOVÁ, J.: Vdát se nebo ne? Motivace vdaných a neprovdaných matek. In Hamplová, D. (ed.) et al.: Déti na psí knížku? Mimomanželská plodnost v $\check{C} R$. 1. vyd.
Praha: Sociologický ústav AV ČR, 2007, s. 59-78. CHALOUPKOVÁ, J., ŠAlAMOUNOVÁ, P.: Postoje $k$ manželství, rodičovství a $k$ rolím v rodině $v$ České re publice a v Evropě. 1. vyd. Praha: Sociologický ústav AV ČR, 2004, $60 \mathrm{~s}$.

CHERLIN, J.: The Deinstitucionalization of American Marriage. Journal of Marriage and Family, 2004, vol. 66, no 4 , s. 848-861.

JÄCKELOVÁ, K.: I tohle je manželství... 1. vyd. Praha: Knižní klub, 1997, 318 s.

KELLER, J.: Soumrak sociálního státu. 1. vyd. Praha: Sociologické nakladatelství (SLON), 2005, 160 s.

KIERNAN, K.: Unmarried Cohabitation and Parenthood in Britain and Europe. LAW \& POLICY, 2004, vol. 26, no 1 , s. 33-55.

KUČERA, M.: Představy o postavení sňatku a narození dětí v životní dráze mladých svobodných lidí. In: Fialová, L. et al.: Představy mladých lidí o manželství a rodičovství. 1. vyd. Praha: Sociologické nakladatelství, 2000. s. 45-66.

KUCHAŘOVÁ, V.: Některé obsahové změny postojů k manželství a rodičovství. In: Mareš, P., Potočný, T. Modernizace a česká rodina. 1. vyd. Brno: Barrister \& Principal, 2003, s. 189-204.

LICHTER, T. D., QIAN, Z: Serial Cohabitation and the Marital Life Course. Journal of Marriage and Family, 2008, vol. 70, no 4, s. 861-878.

MLÁDEK, J., ŠIROČKOVÁ, J.: Kohabitácie ako jedna z foriem partnerského spolužitia obyvatel'stva Slovenska. Sociológia, 2004, vol. 36, no 5, s. 423-454.

MOŽNÝ, I.: Kapitoly ze sociologie rodiny. 1 vyd. Brno: Univerzita J. E. Purkyně, 1987, 143 s.

MOŽNÝ, I.: Proč tak snadno. 2. vyd. Praha: Sociologické nakladatelství (SLON), 1999, $140 \mathrm{~s}$.

MOŽNÝ, I.: Sociologie rodiny. 2. vyd. Praha: Sociologické nakladatelství (SLON), 2002, $250 \mathrm{~s}$.

MOŽNÝ, I., RABUŠIC, L.: Unmarried Cohabitation in Czechoslovakia. Sociologický časopis/Czech Sociological Review, 1992, vol. 28, (Spec. Issue), s. 107-117.

OSBORNE, C., MANNING, D. W., SMOCK, J. P. Married and Cohabiting Parents Relationship Stability: A Focus on Race and Ethnicity. Journal of Marriage and Family, 2007, vol. 69, no 5, s. 1345-1366.

PILINSKÁ, V. et al.: Demografická charakteristika rodiny na Slovensku [online]. 11/2005, [cit. 2010-03-01]. Dostupné Z: <http://www.infostat.sk/vdc/pdf/ rodina2004.pdf>.

PLAŇAVA, I.: Spolu každý sám. Praha: Nakladatelství Lidové noviny, 1998, $218 \mathrm{~s}$.

RABUŠIC, L.: Kde ty všechny děti jsou? 1. vyd. Praha: Sociologické nakladatelství, 2001, $265 \mathrm{~s}$.

SELTZER, A. J.: Families Formed outside of Marriage. Journal of Marriage and the Family, 2000, vol. 62, no 4, s. $1247-1268$

SINGLY, F. de.: Sociologie současné rodiny. 1. vyd. Praha: Portál, 1999. 127 s.

ŠAMANOVÁ, G.: Partnerství, manželství a rodičovství. Tisková zpráva. Sociologický ústav AV ČR, v. v. i. - 12. 1. 2010

ŠMOLKA, P.: Soužití bez svatby [online]. 19. 4. 2002, [cit. 2009-05-04]. Dostupné z: <http://www.rodina.cz/ clanek2465."htm>.

ŠMOLKA. P.: Muž a žena - návod $k$ použití. 1. vyd. Praha: Portál, 2004. 160 s. 
Štatistický úrad Slovenskej republiky. Populačný vývoj v Slovenskej republike 2008 [online]. 10. 12. 2009, [cit. 2010-03-02]. Dostupné z: <http://portal.statistics.sk/ showdoc.do?docid=20020>.

THORNTON, A., AXINN, G. W., HILL, H. D.: Reciprocal Effects of Religiosity, Cohabitation, and Marriage. The American Journal of Sociology, 1992, vol. 98, no 3, s. 628-651.

TUČEK, M.: Vybrané charakteristiky současné české rodiny a jejich vývoj v posledním desetiletí. In: Maříková, H. (ed.): Proměny současné české rodiny. 1. vyd. Praha: Sociologické nakladatelství (SLON), 2000, $170 \mathrm{~s}$.

VÁGNEROVÁ, M.: Vývojová psychologie: dětství, dospělost, stáří. 1. vyd. Praha: Portál, 2000, 528 s.
VYMĚTALOVÁ, S.: Partnerský vztah. In: Fialová, L. et al.: Představy mladých lidí o manželství a rodičovství. 1. vyd. Praha: Sociologické nakladatelství, 2000, s. 99-133.

WALTER, M. R.: High Hopes: Unwed Parent's Expectations about Marriage. Children and Youth Services Review, 2001, vol. 23, no 6/7, s. 457-484.

WU, L., MUSICK, K.: Stability of Marital and Cohabiting Unions Following a First Birth. Population Research and Policy Review, 2008, vol. 27, no 6, s. 713-727.

\section{Miluše Vítečková, Iva Brabcová} mviteckova@pf.jcu.cz 